\title{
Long-Term Effects of Alternative Residue Management Practices on Soil Water Retention in a Wheat-Soybean, Double-Crop System in Eastern Arkansas
}

\author{
Ryan Norman1, Kristofor R. Brye1, Edward E. Gbur², Pengyin Chen1, John Rupe ${ }^{3}$ \\ ${ }^{1}$ Department of Crop, Soil, and Environmental Sciences, University of Arkansas, Fayetteville, USA \\ ${ }^{2}$ Agricultural Statistics Laboratory, University of Arkansas, Fayetteville, USA \\ ${ }^{3}$ Department of Plant Pathology, University of Arkansas, Fayetteville, USA \\ Email: kbrye@uark.edu
}

Received 13 August 2015; accepted 12 September 2015; published 15 September 2015

Copyright (C) 2015 by authors and Scientific Research Publishing Inc.

This work is licensed under the Creative Commons Attribution International License (CC BY). http://creativecommons.org/licenses/by/4.0/

(c) (i) Open Access

\section{Abstract}

Soil water retention is a critical aspect of agricultural management, especially in areas such as the Lower Mississippi River Alluvial Valley that face potential water shortages in the near future. Previous studies have linked changes in soil water retention characteristics to agricultural management practices, especially as they affect the accumulation of soil organic matter (SOM). Therefore, the objective of this study was to determine the relationship between soil water potential and gravimetric soil water content in the top $7.5 \mathrm{~cm}$ as affected by nitrogen (N) fertilization/residue level (high and low), residue burning (burning and non-burning), tillage (conventional and no-tillage), and irrigation (irrigated and non-irrigated) after 12 complete cropping cycles in a wheat (Triticum aestivum L.)-soybean [Glycine max (L.) Merr.], double-crop production system in the Delta region of eastern Arkansas using soil wetting curves. The soil investigated was a Calloway silt loam (fine silty, mixed, active, thermic Glossaquic Fraglossudalf). The slope characterizing the relationship between the natural logarithm of the soil water potential and the gravimetric soil water content was only affected $(P<0.05)$ by the $\mathrm{N}$-fertilization/residue-level treatment, while the intercept was unaffected by any field treatment. Averaged across tillage, burning, and irrigation, soil water contents under the high- exceeded those under low- $\mathrm{N}$-fertilization/residue-level treatment at the same water potential, with the greatest differences observed at water contents > $0.12 \mathrm{~g} \cdot \mathrm{g}^{-1}$. Understanding the ways in which alternative residue management practices affect soil water retention characteristics is an important component of conserving irrigation water resources. 


\section{Keywords}

\section{Water Retention, Tillage, Residue Burning}

\section{Introduction}

Agronomic management practices that promote the formation of soil organic matter (SOM) and soil aggregation, such as reduced tillage and diversifying crop rotations, can increase plant available water in the soil [1] and likely have many more positive, long-term effects on soil water characteristics. For example, significant differences have been observed between soil water retention curves in the top $10 \mathrm{~cm}$ for native prairie (SOM = 22 $\left.\mathrm{g} \cdot \mathrm{kg}^{-1}\right)$ and cultivated agricultural soil ( $\mathrm{SOM}=10.8 \mathrm{~g} \cdot \mathrm{kg}^{-1}$ ) in eastern Arkansas [2]. Specifically, the native prairie soil contained a greater soil water content than the cultivated agricultural soil at the same water potential, indicating a possible correlation between increased SOM and water retention. Similarly, decreased soil water retention under conventional tillage (CT) management was reported compared to increased soil water retention and unsaturated hydraulic conductivity under no-tillage (NT) management in a continuous corn (Zea mays L.) study on Mollisols in Iowa [3]. Verkler et al. [4] reported slower soil dry down after wetting under non-burned management compared to burned residue management, as well as slower soil dry down under NT compared to CT when examining soil water content dynamics in a wheat (Triticum aestivum L.)-soybean [Glycine max (L.) Merr.], double-crop system on a silt-loam soil in eastern Arkansas after three years and four complete cropping cycles. Clearly, residue and field management practices influence soil water retention characteristics, which may be related to agricultural management effects on soil aggregation and SOM.

Increases in SOM have been associated with increased infiltration, greater hydraulic conductivity, and increased water retention [5]. Therefore, management practices such as tillage and nitrogen $(\mathrm{N})$ fertilization that may affect the accumulation of SOM may also affect soil water retention characteristics. In a previous study of alternative residue management practice effects on near-surface soil properties in a wheat-soybean, double-crop production system on a silt-loam soil in eastern Arkansas, Amuri et al. [6] reported increasing soil carbon (C) and SOM over time in the top $10 \mathrm{~cm}$ across all treatment combinations over the course of six years and seven complete wheat-soybean cropping cycles following conversion to alternative management practices, where trends were likely due to the increase in crop residue returned to the soil as a result of converting from monoculture soybean to a wheat-soybean double-crop system. Smith et al. [7] reported that the abundance of water-stable aggregates was significantly affected by tillage, irrigation, and $\mathrm{N}$-fertilization treatments. Nitrogen fertilization promotes wheat biomass, which may eventually contribute to an increase in SOM and soil aggregation. Therefore, $\mathrm{N}$ fertilization, and other management practices that promote SOM and soil aggregation, may affect the relationship between soil water potential and the soil water content, hence soil water retention. For example, Bowman and Halvorson [8] reported significant increases in soil organic C (SOC), and therefore SOM, in the top $5 \mathrm{~cm}$ under increased $\mathrm{N}$-fertilization management. Similarly, SOC and SOM increased at a greater rate under a high $\left(134 \mathrm{~kg} \cdot \mathrm{N} \cdot \mathrm{ha}^{-1} \cdot \mathrm{yr}^{-1}\right)$ than under low N-rate $\left(<90 \mathrm{~kg} \cdot \mathrm{N} \cdot \mathrm{ha}^{-1} \cdot \mathrm{yr}^{-1}\right)$ treatments in a wheat-containing rotation managed consistently for 10 yr near Akron, Colorado [9].

An understanding of traditional and alternative residue management practices on soil water retention is critical to determining the best management practices in highly productive agricultural regions, especially in areas such as the Delta region of eastern Arkansas that face potential water shortages in the future. Scott et al. [10] used a regression equation based on annual water use rate to determine that $75 \%$ of the Alluvial Aquifer, the shallowest aquifer underlying most of the Delta region of eastern Arkansas, will be depleted from large irrigation withdrawls by 2041. Therefore, the objective of this study was to examine the effects of $\mathrm{N}$ fertilization/residue level (high and low), residue burning (burning and non-burning), tillage (conventional and no-tillage), and irrigation (irrigated and non-irrigated) on the relationship between soil water potential and gravimetric soil water content in the top $7.5 \mathrm{~cm}$ after 12 complete cropping cycles in a wheat-soybean, double-crop production system in eastern Arkansas using soil wetting curves. It was hypothesized that water contents under NT will be greater than that under CT at the same water potential due to effects on aggregation and that the history of irrigation or dryland production will have little effect on soil water retention using the wetting curve approach. It was also hypothesized that the cumulative effects of 12 years of residue burning would render soil water retention in the 
burned treatment lower than that in the non-burned treatment due to the hydrophobic characteristics of the added ash. In addition, it was hypothesized that increased above and belowground biomass inputs would contribute to greater water retention in the high than in the low $\mathrm{N}$-fertilization/residue-level treatment.

\section{Materials and Methods}

\subsection{Site Description}

A field study was initiated in Fall 2001 at the Lon Mann Cotton Branch Experiment Station (N34 44'2.26"; W90 45'51.56") [11] in the Lower Mississippi River Alluvial Valley near Marianna, AR. The study site lies within the Southern Mississippi Valley Loess [Major Land Resource Area (MLRA) 134] [12]. This region consists of a series of loess covered hills and alluvial terraces. Despite being prone to erosion, this region has been highly agriculturally productive for decades [12]. The field site is on a Calloway silt loam (fine silty, mixed, active, thermic Glossaquic Fraglossudalf) [13], which consists of $16 \%$ sand, $73 \%$ silt, and $11 \%$ clay in the top 10 $\mathrm{cm}$ [14]. The 30-yr mean air annual temperature of the region is $15.6^{\circ} \mathrm{C}$ and the 30 -yr mean annual precipitation is $128 \mathrm{~cm}$ [15]. The 30-yr mean maximum and minimum air temperatures of the region are $32.8^{\circ} \mathrm{C}$ in July and $2.4^{\circ} \mathrm{C}$ in January, respectively [15]. This study follows a series of several previous studies at this same study site that have evaluated a variety of short- and long-term effects of alternative management practices effects on plant and soil properties [6] [7] [16].

\subsection{Experimental Design}

Between Fall 2001 and Spring 2005, the study consisted of a three-factor, split-strip-plot, randomized complete block experimental design with six replications of each of eight treatment combinations [11]. The three experimental factors were i) $\mathrm{N}$ fertilization/residue level (i.e., a high $\mathrm{N}$ fertilization/residue level, achieved with a split application of $\mathrm{N}$ fertilizer, and a low $\mathrm{N} /$ fertilization/residue level, achieved with minimal to no $\mathrm{N}$ additions); ii) residue burning (i.e., burning or non-burning); and iii) tillage (i.e., CT or NT) [11]. However, an irrigation factor was introduced in 2005 by dividing the site into an irrigated half and a non-irrigated half [4]. Since 2005, the experimental area has consisted of 48, 3- $\times 6$-m plots with six replications for every $\mathrm{N}$-fertilization/residue-level-burning-tillage treatment combination and three replications for every $\mathrm{N}$-fertilization/residue-level-burningtillage-irrigation treatment combination (Figure 1) [6].

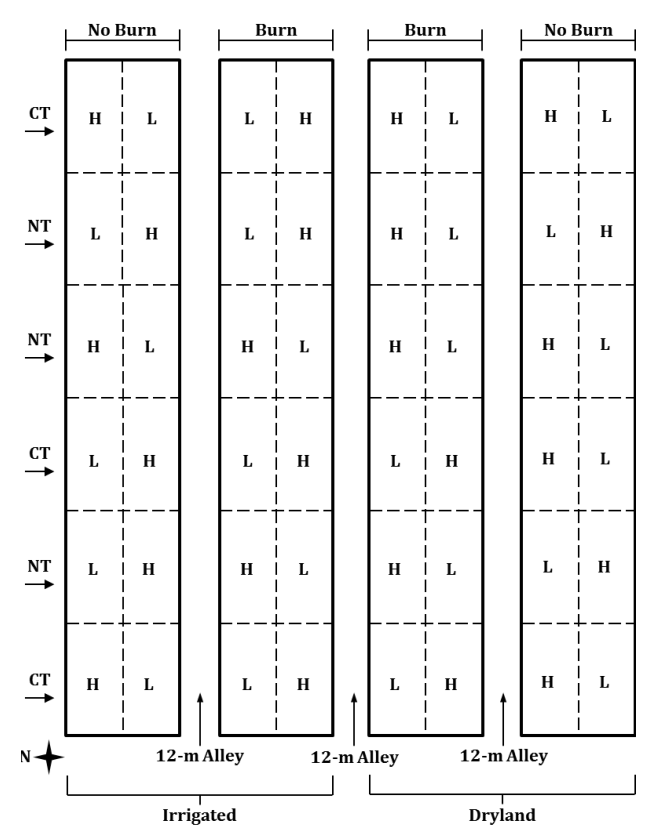

Figure 1. Experimental layout at the Lon Mann Cotton Branch Experiment Station in eastern Arkansas depicting 48, 3- $x$ 6-m plots under residue-level [high (H) and low (L)], burn, tillage [conventional tillage (CT) and no-tillage (NT)], and irrigation treatments. 


\subsection{Field Management}

Prior to the initiation of the study, the site was managed as a continuous, mono-cropped soybean system using CT [11]. Due to the consistent field management prior to beginning this long-term study in 2001, near-surface soil properties throughout entire study area were assumed uniform and any subsequent observed differences in measured soil and/or plant properties were assumed be to the result of imposed field treatments rather than inherent differences among plots [14].

To prepare for this study, initial field preparations in Fall 2001 involved disking twice followed by broadcast applications of N, phosphorous, potassium, and pelletized limestone at rates of 20, 22.5, 56, and $1120 \mathrm{~kg} \cdot \mathrm{ha}^{-1}$, respectively, prior to wheat planting. Wheat was drill seeded with a 19-cm row spacing each fall thereafter. All plots were manually broadcast fertilized in early March 2002 through 2004 with urea (46\% N) at the rate of 101 $\mathrm{kg} \cdot \mathrm{N} \cdot \mathrm{ha}^{-1}$. High-N-fertilization/residue-level plots $(\mathrm{n}=24)$ were manually broadcast fertilized in late March at approximately the late-jointing stage with an additional $101 \mathrm{~kg} \cdot \mathrm{N} \cdot \mathrm{ha}{ }^{-1}$ to produce different levels of wheat residue. No N-fertilizer was applied in Spring 2005 due to a failure to establish wheat stands caused by prolonged wet soil conditions in Fall 2004. Since 2006, initial applications of $56 \mathrm{~kg} \cdot \mathrm{N} \cdot \mathrm{ha}^{-1}$ as urea were broadcast on high$\mathrm{N}$-fertilization/residue-level plots in approximately late February, followed by a split application of an additional $56 \mathrm{~kg} \cdot \mathrm{N} \cdot \mathrm{ha}^{-1}$ at the late-jointing stage in approximately late March. Since 2006, the low-N-fertilization/residuelevel plots have received no $\mathrm{N}$ fertilization in order to achieve the desired residue-level difference.

Wheat was harvested using a plot combine in approximately early June each year. Wheat residue left behind the plot combine was uniformly spread by hand over each plot immediately following wheat harvest. Any remaining wheat stubble was mowed with a rotary mower to a height of $\sim 3 \mathrm{~cm}$ from the soil surface in order to achieve a uniform residue-covered surface for soybean planting. Following mowing, the burning treatment was imposed on half of the plots by propane flaming. The residue-burning treatment was not able to be imposed in 2005, 2007, and 2012 due to the absence of a wheat stand in Spring 2005, prolonged wet soil conditions in Spring 2007, and overly weedy conditions in 2012. Imposition of the burning treatment was followed by impos ing the tillage treatment each year. The CT plots were disked at least twice with a tandem disk to a depth of 10 $\mathrm{cm}$ followed by seedbed smoothing with at least three passes of a soil conditioner. The CT practices used in this study are representative of widely used pre-soybean-planting tillage operations throughout the region.

A glyphosate-resistant soybean cultivar, maturity group 5.3 or 5.4 , was drill-seeded with $19-\mathrm{cm}$ row spacing at a rate of approximately $47 \mathrm{~kg}$ seed ha ${ }^{-1}$ in early to mid-June each year. Potassium fertilizer was applied according to recommended rates [17] when the previous year's soil test indicated potassium was needed. In 2002 through 2004, all plots were furrow-irrigated as needed, three to four times each soybean-growing season. A levee was created in 2005 to exclude furrow-irrigation water from the non-irrigated (i.e., dryland) treatment, which received only natural rainfall. Weeds and insects were managed consistently throughout the entire study area as necessary based on University of Arkansas Cooperative Extension Service's recommendations, which generally consisted of herbicide and insecticide applications during both the wheat- and soybean-growing seasons [17]. Soybean were harvested with a plot combine from late October to early November each year. Each year within two weeks of soybean harvest, the subsequent wheat crop was sown into the soybean residue, which was left in place without any manipulations.

\subsection{Plant Sample Collection and Processing}

To verify achievement of the N-fertilization/residue-level treatment, immediately following wheat harvest and rotary mowing and before residue burning each year, aboveground residue was assessed. A residue sample was collected from within a $0.25-\mathrm{m}^{2}$ metal frame, oven-dried for 3 to 7 days at $55^{\circ} \mathrm{C}$, and weighed to obtain an estimate of aboveground residue mass into which soybean were subsequently planted.

\subsection{Soil Sample Collection and Processing}

Consistent with prior annual soil sampling conducted at this field site [6] [7] [14] [16], at wheat harvest in May 2014, a single soil sample was collected from the top $10 \mathrm{~cm}$ in each plot using a 4.8-cm-diameter stainless steel core chamber beveled to the outside to minimize compaction. Soil samples were oven-dried for $48 \mathrm{hr}$ at $70^{\circ} \mathrm{C}$, weighed for bulk density determinations, ground to pass through a 2-mm mesh screen, and analyzed for selected soil chemical properties. Soil $\mathrm{pH}$ was determined potentiometrically in a 1:2 (w/v) soil-to-water suspension. Soil $\mathrm{OM}$ was determined by weight-loss-on-ignition after $2 \mathrm{hr}$ at $360^{\circ} \mathrm{C}$. Total soil $\mathrm{C}$ and $\mathrm{N}$ were determined by 
high-temperature combustion with an Elementar VarioMAX Total C and N Analyzer (Elementar Americas Inc., Mt. Laurel, NJ). All measured soil C was assumed to be organic given the lack of effervescence upon treatment with dilute hydrochloric acid [14]. The soil C: $\mathrm{N}$ ratio was calculated from measured $\mathrm{C}$ and $\mathrm{N}$ concentrations. Total C and $\mathrm{N}$ and SOM contents $\left(\mathrm{kg} \cdot \mathrm{m}^{-2}\right)$ were calculated from measured concentrations $\left(\mathrm{g} \cdot \mathrm{kg}^{-1}\right)$ and measured bulk densities in the top $10 \mathrm{~cm}$ from the May 2014 soil sampling.

To assess field treatment effects on the relationship between soil water potential and soil water content, 12, $\sim 2$-cm-diameter soil samples were collected from the top $7.5 \mathrm{~cm}$ of each plot at wheat harvest in May 2014 and combined into one composite soil sample per plot. Each sample was manually homogenized and air-dried for approximately $5 \mathrm{~d}$, ground, and sieved to pass through a 2-mm mesh screen. Subsamples were weighed, oven-dried at $70^{\circ} \mathrm{C}$ for $48 \mathrm{hr}$, and reweighed to obtain the initial moisture content of the air-dried sample. Following the procedures of Brye [2], seven, $5 \pm 0.01$-g subsamples of air-dried soil from each of the 48 plots were added to small mixing cups. Drops of distilled water (i.e., 2, 4, 6, 10, 12, 15, and 20 drops) were added to each of the seven mixing cups with an eyedropper and manually mixed with a spatula to achieve a range of gravimetric soil water contents. The moist soil in each mixing cup was transferred to small plastic instrument cups, $4 \mathrm{~cm}$ in diameter by $1 \mathrm{~cm}$ tall, and lightly packed to a uniform bulk density of $\sim 0.7 \mathrm{~g} \cdot \mathrm{cm}^{-3}$. The plastic instrument cups were capped and allowed to equilibrate overnight to room temperature (i.e., $\sim 20^{\circ} \mathrm{C}$ ). The next morning after over-night temperature equilibration, the water potential was subsequently measured with a WP4 Dewpoint PotentiaMeter (Decagon Devices, Inc., Pullman, WA), which was calibrated using a standard potassium chloride solution. After the water potential was recorded, each instrument cup was weighed, oven-dried at $70^{\circ} \mathrm{C}$ for $48 \mathrm{hr}$, then reweighed for gravimetric water content determinations. Measured water potentials were natural-logarithm transformed to facilitate statistical analyses.

In addition, to determine actual residue management effects on near-surface bulk density, a third set of soil cores were collected between 8 and 10 weeks after soybean planting in 2014, similar to previous annual bulk densities assessments [6] [7] [14] [16]. A single 4.8-cm-diameter soil core was extracted from the top $10 \mathrm{~cm}$ in each plot using a stainless steel core chamber and slidehammer. Samples were oven-dried at $70^{\circ} \mathrm{C}$ for $48 \mathrm{hr}$, and weighed for an additional bulk density measurement.

\subsection{Statistical Analyses}

An analysis of variance (ANOVA) was conducted using SAS (version 9.3, SAS Institute, Inc., Cary, NC) to evaluate the $\mathrm{N}$-fertilization/residue-level treatment effect on aboveground residue mass for annual measurements conducted between 2007 and 2014. In addition, an ANOVA was also conducted using SAS, based on the stripsplit-plot experimental layout of the field treatments (Figure 1), to evaluate the effects of $\mathrm{N}$ fertilization/residue level, burning, tillage, irrigation, and their interactions on soil $\mathrm{pH}, \mathrm{SOM}$, total $\mathrm{N}$, and $\mathrm{C}$ contents, C: $\mathrm{N}$ ratio, and bulk density in the top $10 \mathrm{~cm}$ measured in 2014, which represents the cumulative effects of 12 consecutive years of consistent management. Due to practical limitations of the study area, the addition of the irrigation treatment since 2005 was superimposed on the burning treatment (Figure 1). Therefore, irrigation and burning treatments could not be simultaneously analyzed within this experimental design. Therefore, two separate ANOVAs were conducted, each excluding one of the confounding factors (i.e., burning and irrigation). When appropriate, treatment means were also separated by least significant difference (LSD) at the 0.05 level.

To evaluate field treatment effects on soil water retention, an analysis of covariance (ANCOVA) was conducted using SAS to examine the long-term effects of $\mathrm{N}$ fertilization/residue level, burning, tillage, irrigation, and their interactions on the linear relationship between the natural logarithm (log) of the measured soil water potential and the gravimetric water content from the soil wetting-curve data. For the purposes of simultaneously evaluating all field treatments and their interactions, the experimental design was assumed to be completely random with three replications of each of 16 treatment combinations. The full ANCOVA model was reduced using a hierarchal principle to remove non-significant terms, and non-significant terms were only included the final model when they participated in higher-order, complex treatment interactions. When appropriate, treatment means for slopes and intercepts from the log-transformed relationships were separated by LSD at the 0.05 level.

\section{Results and Discussion}

\subsection{Aboveground Residue Levels}

Following the 13 wheat crops produced in this study between 2002 and 2014, the N-fertilization scheme used 
annually produced numerically greater aboveground residue amounts, into which the subsequent soybean crop was planted, in the high than in the low N-fertilization/residue-level treatment in 12 of the 13 years, with 2002 being the exception [6] [18]. In addition, significantly $(P<0.05)$ greater aboveground residue amounts were produced in the high than in the low $\mathrm{N}$-fertilization/residue-level treatment in 10 of the 13 years, with 2002, 2004 [6], and 2010 being the exceptions [18]. Therefore, it is clear that the intended residue-level differences were achieved in more than the majority of the 13 years to justify the $\mathrm{N}$-fertilization/residue-level treatment.

\subsection{Soil Properties}

After 13 complete wheat-soybean cropping cycles (i.e., 2001 to 2014) and 12 years of consistent management, soil $\mathrm{C}$ and $\mathrm{N}$ contents, soil C:N ratio, and soil $\mathrm{pH}$ in the top $10 \mathrm{~cm}$ were affected $(P<0.05)$ by field treatments. When irrigation was excluded from the model, soil C content $(P=0.038)$ and soil $\mathrm{C}$ : $\mathrm{N}$ ratio $(P=0.033)$ differed between burn treatments in 2014. Averaged across tillage, $\mathrm{N}$ fertilization/residue level, and irrigation, soil C content averaged 1.22 and $1.42 \mathrm{~kg} \cdot \mathrm{m}^{-2}$, while the soil C:N ratio averaged 9.2 and 10.2 under burning and nonburning, respectively. However, when burning was excluded from the model, soil $\mathrm{N}$ content $(P=0.032)$ and the C:N ratio $(P=0.021)$ differed between the $\mathrm{N}$-fertilizer/residue-level treatments (Table 1$)$. Averaged across tillage, burning, and irrigation, soil $\mathrm{N}$ content averaged 0.14 and $0.13 \mathrm{~kg} \cdot \mathrm{m}^{-2}$ under the high and low $\mathrm{N}$-fertilization/residue-level treatments, respectively. Similarly, averaged across tillage, burning, and irrigation, the soil C: $\mathrm{N}$ ratio averaged 9.4 and 10.0 under the high and low $\mathrm{N}$-fertilization/residue-level treatments, respectively.

In 2014, soil $\mathrm{pH}$ in the top $10 \mathrm{~cm}$ differed $(P=0.021)$ between irrigation treatments within $\mathrm{N}$-fertilizer/residue-level treatments (Table 1 ) when burning was excluded from the model. Averaged across tillage and burning, soil $\mathrm{pH}$ was greater under irrigation regardless of $\mathrm{N}$-fertilization/residue level, where soil $\mathrm{pH}$ averaged 7.26 under the high and 7.28 under the low $\mathrm{N}$ fertilization/residue level, than that under the dryland treatment, where soil $\mathrm{pH}$ averaged 6.67 under the low, which was greater than that under the high $\mathrm{N}$ fertilization/residue level (i.e., $\mathrm{pH}$ averaged 6.48). However, all soil $\mathrm{pH}$ values, regardless of management, exceeded the minimum soil $\mathrm{pH}$ threshold of 6.0, below which soybean yield reductions can be expected on silt-loam soils in eastern Arkansas [19]. Therefore, the differences in soil $\mathrm{pH}$ among irrigation and $\mathrm{N}$-fertilization/residue-level treatment combinations were agronomically non-significant with regards to soybean production on silt-loam soils in eastern Arkansas.

In contrast to other initial soil properties, after 13 complete wheat-soybean cropping cycles (i.e., 2001 to 2014) and 12 years of consistent management, bulk density and SOM contents were unaffected $(P>0.05)$ by any of the field treatments in 2014 regardless of whether burning (Table 1) or irrigation (data not shown) were excluded in the statistical model. Therefore, bulk density averaged $1.21 \mathrm{~g} \cdot \mathrm{cm}^{-3}$ [standard error (SE) $=0.01$ ] and SOM content averaged $2.9 \mathrm{~kg} \cdot \mathrm{m}^{-2}(\mathrm{SE}=0.06)$ across all field treatments in 2014 .

Table 1. Analysis of variance summary of the effects of $\mathrm{N}$-fertilization/residue level (residue level), tillage, irrigation, and their interactions on soil bulk density, $\mathrm{pH}$, soil organic matter (SOM), total carbon (TC), total nitrogen (TN), and the soil C: $\mathrm{N}$ ratio in the top $10 \mathrm{~cm}$ from spring 2014 after 12 complete cropping cycles in a wheat-soybean, double-crop production system in eastern Arkansas.

\begin{tabular}{|c|c|c|c|c|c|c|}
\hline Source of Variation & Bulk Density & $\mathrm{pH}$ & SOM & TC & $\mathrm{TN}$ & $\mathrm{C}: \mathrm{N}$ \\
\hline & \multicolumn{6}{|c|}{$P$} \\
\hline Residue level & $\mathrm{ns}^{\dagger}$ & ns & ns & ns & 0.032 & 0.021 \\
\hline Tillage & ns & ns & ns & ns & ns & ns \\
\hline Irrigation & ns & 0.023 & ns & ns & ns & ns \\
\hline Residue level $\times$ tillage & ns & ns & ns & ns & ns & ns \\
\hline Residue level $\times$ irrigation & ns & 0.021 & ns & ns & ns & ns \\
\hline Tillage $\times$ irrigation & ns & ns & ns & ns & ns & ns \\
\hline Residue level $\times$ tillage $\times$ irrigation & ns & ns & ns & ns & ns & ns \\
\hline
\end{tabular}

\footnotetext{
${ }^{\dagger}$ Not significant (ns, $\left.P>0.05\right)$.
} 


\subsection{Soil Water Retention}

As was expected, the relationship between soil water potential and gravimetric water content across all data and treatment combinations followed a curvilinear pattern, where the water potential increased exponentially as gravimetric soil water content increased (Figure 2). Though soil properties, and water retention, were assumed to be uniform at the beginning of the study site in 2001, after 13 complete wheat-soybean cropping cycles (i.e., 2001 to 2014) and 12 years of consistent management, the slope characterizing the linear relationship between the natural logarithm of water potential and gravimetric water content in the top $7.5 \mathrm{~cm}$ was affected $(P=0.007)$ by only the N-fertilization/residue-level treatment (Table 2; Figure 3), and was unaffected $(P>0.05)$ by tillage, burning, irrigation or any of their interactions (Table 3). The intercept characterizing the linear relationship between the natural logarithm of water potential and gravimetric water content was unaffected $(P>0.05)$ by any field treatment (Table 2; Figure 3). Averaged across tillage, burning, and irrigation, the slope for the low was greater (i.e., more negative) than that for the high $\mathrm{N}$-fertilization/residue-level treatment (Table 3). This result indicated that, on average, there was a greater change in water content per unit change in water potential associated with the soil from the low compared to the high $\mathrm{N}$-fertilization/residue-level treatment. The greatest differences between high and low $\mathrm{N}$-fertilization/residue treatments were observed at water contents $>\sim 0.12 \mathrm{~g} \cdot \mathrm{g}^{-1}$ (Figure 3). Conversely, as soil water potential decreased, gravimetric soil water contents became increasingly similar under both $\mathrm{N}$-fertilization/residue-levels treatments.

The results of this study on a silt-loam, loessial soil from the Delta region of eastern Arkansas were similar to the soil moisture characteristic curve results reported by Brye [2] using a similar wetting-curve approach. Brye [2] demonstrated that soil water contents in both native prairie and cultivated agricultural silt-loam soils in eastcentral Arkansas became increasingly similar as soil water potential approached permanent wilting point (i.e., $-1.5 \mathrm{MPa}$ ), regardless of field treatments imposed. Verkler et al. [4] also reported numerically greater maximum soil water contents at the $7.5 \mathrm{~cm}$ depth under the high compared with the low N-fertilization/residue-level treatment, although the differences were statistically non-significant. Management practices that increase the amount of crop residue returned to the soil, such as with greater above- and belowground biomass achieved with differential $\mathrm{N}$ fertilization, have been shown to increase infiltration, bulk density, and water storage capacity [20].

Though $\mathrm{N}$ fertilization/residue level did not significantly affect SOM or C contents in the top $10 \mathrm{~cm}$ in 2014 after 13 years of consistent residue management, one possible explanation for the significant effect of $\mathrm{N}$ fertili-

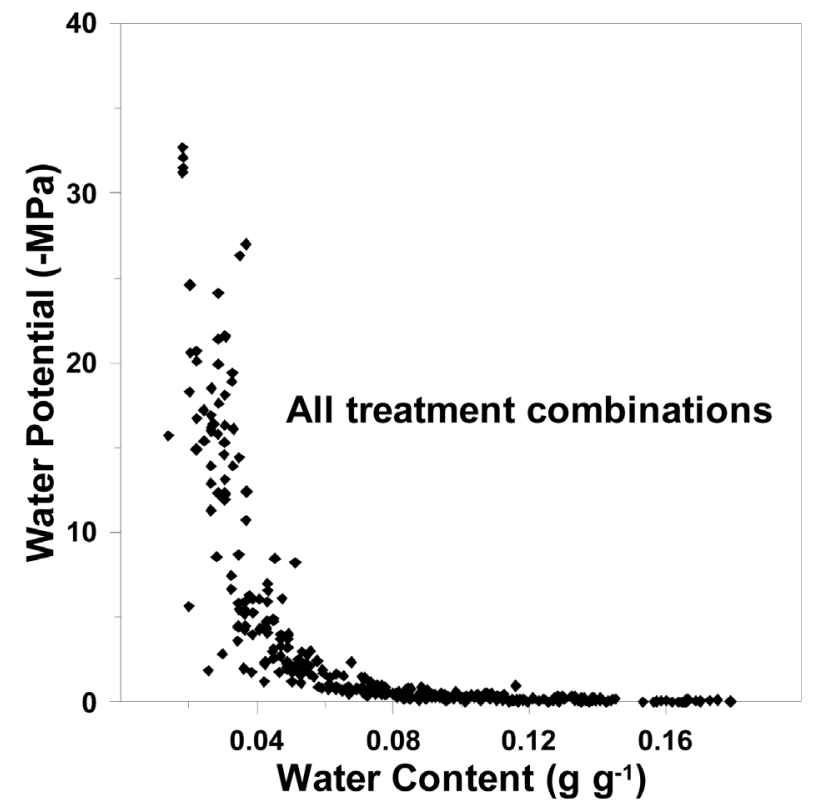

Figure 2. Raw data from all treatment combinations depicting the relationship between soil water potential and gravimetric soil water content from soil wetting curves for the top $7.5 \mathrm{~cm}$ in a wheat-soybean, double-crop system in eastern Arkansas after 13 years (i.e., 2001 to 2014) of consistent residue management. 
Table 2. Analysis of covariance summary of the effects of N-fertilization/residue level (residue level), burning (burn), tillage, irrigation, and their interactions on the linear relationship between the natural logarithm of soil water potential and gravimetric soil water content using a soil wetting curve approach from the top $7.5 \mathrm{~cm}$ after 12 complete cropping cycles in a wheat-soybean, double-crop production system in eastern Arkansas.

\begin{tabular}{|c|c|}
\hline Source of variation ${ }^{\dagger}$ & $P$ \\
\hline \multicolumn{2}{|l|}{ Intercept term } \\
\hline Residue level & $\mathrm{ns}^{\dagger \dagger}$ \\
\hline Burn & ns \\
\hline Tillage & ns \\
\hline Irrigation & ns \\
\hline Residue level $\times$ burn & ns \\
\hline Residue level $\times$ tillage & ns \\
\hline Residue level $\times$ irrigation & ns \\
\hline Burn $\times$ tillage & ns \\
\hline Burn $\times$ irrigation & ns \\
\hline Tillage $\times$ irrigation & ns \\
\hline Residue level $\times$ burn $\times$ tillage & ns \\
\hline Residue level $\times$ burn $\times$ irrigation & ns \\
\hline Residue level $\times$ tillage $\times$ irrigation & ns \\
\hline Burn $\times$ tillage $\times$ irrigation & ns \\
\hline Residue level $\times$ burn $\times$ tillage $\times$ irrigation & ns \\
\hline \multicolumn{2}{|l|}{ Liner term } \\
\hline Water content & $<0.001$ \\
\hline Residue level $\times$ water content & 0.007 \\
\hline Burn $\times$ water content & ns \\
\hline Tillage $\times$ water content & ns \\
\hline Irrigation $\times$ water content & ns \\
\hline Residue level $\times$ burn $\times$ water content & ns \\
\hline Residue level $\times$ tillage $\times$ water content & ns \\
\hline Residue level $\times$ irrigation $\times$ water content & ns \\
\hline Burn $\times$ tillage $\times$ water content & ns \\
\hline Burn $\times$ irrigation $\times$ water content & ns \\
\hline Tillage $\times$ irrigation $\times$ water content & ns \\
\hline Residue level $\times$ burn $\times$ tillage $\times$ water content & ns \\
\hline Residue level $\times$ burn $\times$ irrigation $\times$ water content & ns \\
\hline Residue level $\times$ tillage $\times$ irrigation $\times$ water content & ns \\
\hline Burn $\times$ tillage $\times$ irrigation $\times$ water content & ns \\
\hline Residue level $\times$ burn $\times$ tillage $\times$ irrigation $\times$ water content & ns \\
\hline
\end{tabular}

${ }^{\dagger}$ Non-significant interactions $(P>0.05)$ were removed in the final model, except when non-significant terms participated in higher-order, complex treatment combinations. ${ }^{\dagger \dagger}$ Not significant (ns, $P>0.05$ ). 


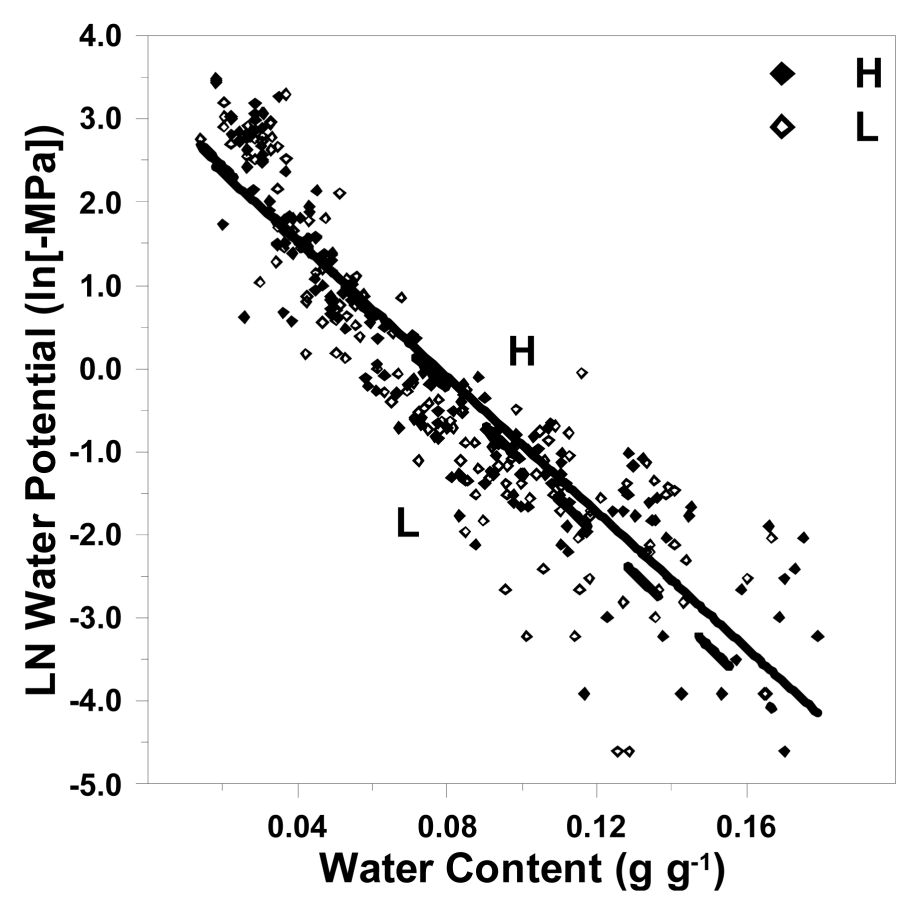

Figure 3. Influence of residue level [high $(\mathrm{H},-$ ) and low $(\mathrm{L},-----)]$ on the relationship between the natural logarithm (LN) of the water potential and the gravimetric soil water content from soil wetting curves for the top $7.5 \mathrm{~cm}$ in a wheat-soybean, double-crop system in eastern Arkansas after 13 years (i.e., 2001 to 2014) of consistent residue management.

Table 3. Summary of estimated regression parameters for the $\mathrm{N}$-fertilization/residue-level [High (H) and Low (L)] treatment for the linear relationship between the natural logarithm of soil water potential (-MPa) and gravimetric soil water content $\left(\mathrm{g} \cdot \mathrm{g}^{-1}\right)$ in the top $7.5 \mathrm{~cm}$ after 12 complete cropping cycles in a wheat-soybean, double-crop production system in eastern Arkansas. Coefficient estimates with the same lower case letter do not differ $(P>0.05)$.

\begin{tabular}{cccc}
\hline Regression Term & Treatment & Coefficient Estimate & $P^{\dagger}$ \\
Intercept & High & $3.108 \mathrm{a}$ & $<0.001$ \\
& Low & $3.357 \mathrm{a}$ & 0.002 \\
Linear & High & $-39.712 \mathrm{a}$ & $<0.001$ \\
& Low & $-45.207 \mathrm{~b}$ & 0.001 \\
\hline
\end{tabular}

${ }^{\dagger} P<0.05$ indicates coefficient estimate was significantly different from 0.

zation/residue level on the relationship between the natural logarithm of water potential and the gravimetric soil water content was that the high $\mathrm{N}$-fertilization/residue-level treatment promoted increased soil structure development and SOM more than the low N-fertilization/residue-level treatment. While it was concluded in a previous study analyzing soil properties in the same plots used in the current study that $\mathrm{N}$ fertilization/residue level alone had no obvious, observable effects on the trend in SOM content in the top $10 \mathrm{~cm}$ over time between 2007 and 2014, N fertilization/residue level did affect $(P<0.05)$ the trend in SOM content over time as part of complex treatment combinations [18].

It is also possible that the $\mathrm{N}$-fertilization/residue-level treatment may have impacted SOM content and soil aggregates in the top $7.5 \mathrm{~cm}$ differently than in the top $10 \mathrm{~cm}$ due to the greater accumulation of both above- and below-ground plant biomass concentrated near the soil surface. A previous study analyzing soil aggregation in the top $10 \mathrm{~cm}$ in the same plots used in the current study reported that the concentration of water-stable aggregates was $11 \%$ greater in the top $5 \mathrm{~cm}$ than in the 5 to $10 \mathrm{~cm}$ depth interval after 7 years of consistent management [7] suggesting that SOM and soil aggregates may be more concentrated in the 7.5-cm depth samples used for the current study than in the 10-cm depth samples used for previous studies [6] [18]. Therefore, it is possible that the $\mathrm{N}$-fertilization/residue-level treatment affected the $<2$-mm-sized soil aggregates, which may have oc- 
cluded SOM, in the top $7.5 \mathrm{~cm}$, without clearly and obviously affecting SOM contained in the aggregate size classes larger than $2 \mathrm{~mm}$ in the top $10 \mathrm{~cm}$. Such an increase in occluded SOM in smaller aggregates might account for an increase in soil water content [5] [21]. For example, Brye [2] reported greater soil water contents in the top $10 \mathrm{~cm}$ of a native prairie soil than soil water contents of cultivated agricultural soils at the same water potential and ascribed at least a partial explanation to the greater SOM content in the prairie soil (SOM = 22 $\left.\mathrm{g} \cdot \mathrm{kg}^{-1}\right)$ compared wo the cultivated agricultural soil $\left(\mathrm{SOM}=10.8 \mathrm{~g} \cdot \mathrm{kg}^{-1}\right)$ examined.

Somewhat surprisingly, neither burning nor tillage had an observable effect $(P>0.05$; Table 2$)$ on the relationship between the natural logarithm of water potential and the gravimetric soil water content after 13 years of consistent residue management and 12 complete cropping cycles. These results were in contrast with the original hypothesis that tillage would strongly affect the relationship between soil water potential and soil water content, such that soil water content under NT would exceed that under CT at the same water potential. Similarly, these results were in contrast to the original hypothesis that residue burning would render soil retention in the burned treatment lower than that in the non-burned treatment due to cumulative effects of hydrophobic ash additions. It is possible that any potential effects of burning and/or tillage on water retention characteristics were masked as a result of the sample preparation procedure (i.e., grinding and sieving to $\leq 2 \mathrm{~mm}$ ), which rendered the soil structure and natural aggregation and porosities highly disrupted from their in-situ, undisturbed state. As hypothesized, the cumulative effects of irrigation or dryland soybean production had no effect on resulting water retention characteristics as determined using soil wetting curves.

In contrast to the results of this study, other soil water retention studies have reported significant correlations between cultivation and near-surface soil water retention characteristics [2] [3] [5], likely due to the increased hydraulic conductivity and infiltration rates associated with relatively undisturbed NT compared to highly disturbed CT soils. Verkler et al. [4] reported that residue burning significantly affected maximum soil water contents during irrigation events, and that the mean maximum soil water content was $3 \%(v / v)$ greater under residue burning compared with non-burning. However, the water content measurements conducted by Verkler et al. [4] were made in-situ (i.e., in undisturbed soil in the field), and are therefore fundamentally different from the ovendried, ground, sieved, and rewetted soil samples used in the current study.

\section{Conclusion}

Following conversion to alternative residue and water management practices and after 13 consecutive years (i.e., 2001 to 2014) of management, $\mathrm{N}$ fertilization/residue level, but not burning, tillage, or irrigation treatments, significantly affected the linear relationship between the natural logarithm of water potential and the gravimetric soil water content as determined by soil wetting curves. The wetting-curve procedure provided a simple, replicatable, and useful approach to evaluate long-term effects of various field treatment on soil water retention. It can be inferred from the results of this study that differences in N-fertilization/residue-level management can have a cumulative effect on soil water retention characteristics, possibly as a result of the increased soil aggregation and occluded SOM associated with increased crop residue inputs, both above-and belowground, under a high compared to a low residue-level management scheme. Consideration of soil water retention characteristics is vital to planning sustainable use of irrigation water, especially in areas such as the Delta region of eastern Arkansas that will face potential water shortages in the near future.

\section{Acknowledgements}

Field assistance provided by Matt Gregory at the Cotton Branch Experiment Station is gratefully acknowledged. This work was funded by the Arkansas Soybean Research and Promotion board.

\section{References}

[1] Nielsen, D.C., Vigil, M.F., Anderson, R.L., Bowman, R.A., Benjamin, J.G. and Halvorson, A.D. (2002) Cropping System Influence on Planting Water Content and Yield of Winter Wheat. Agronomy Journal, 94, 962-967. http://dx.doi.org/10.2134/agronj2002.0962

[2] Brye, K.R. (2003) Long-Term Effects of Cultivation on Particle Size and Water-Retention Characteristics Determined using Wetting Curves. Soil Science, 168, 459-468. http://dx.doi.org/10.1097/01.ss.0000080331.10341.36

[3] Hill, R.L., Horton, R. and Cruse, R.M. (1985) Tillage Effects on Soil Water Retention and Pore Size Distribution of Two Mollisols. Soil Science Society of America Journal, 49, 1264-1270. 
http://dx.doi.org/10.2136/sssaj1985.03615995004900050039x

[4] Verkler, T.L., Brye, K.R., Gbur, E.E., Popp, J.H. and Amuri, N. (2008) Residue Management and Water Delivery Effects on Season-Long Surface Soil Water Dynamics in Soybean. Soil Science, 173, 444-455. http://dx.doi.org/10.1097/SS.0b013e31817b6687

[5] Azooz, R.H. and Arshad, M.A. (1996) Soil Infiltration and Hydraulic Conductivity under Long-Term No-Tillage and Conventional Tillage Systems. Canadian Journal of Soil Science, 76, 143-152. http://dx.doi.org/10.4141/cjss96-021

[6] Amuri, N., Brye, K.R., Gbur, E.E., Popp, J. and Chen, P. (2008) Soil Property and Soybean Yield Trends in Response to Alternative Wheat Residue Management Practices in a Wheat-Soybean, Double-Crop Production System in Eastern Arkansas. Journal of Integrative Biosciences, 6, 64-86.

[7] Smith, S.F., Brye, K.R., Gbur, E.E., Chen, P. and Korth, K. (2014) Residue and Water Management Effects on Aggregate Stability and Aggregate-Associated Carbon and Nitrogen in a Wheat-Soybean, Double-Crop System. Soil Science Society of America Journal, 78, 1378-1391. http://dx.doi.org/10.2136/sssaj2013.12.0534

[8] Bowman, R.A. and Halvorson, A.D. (1998) Soil Chemical Changes after Nine Years of Differential N Fertilization in a No-Till Dryland Wheat-Corn-Fallow Rotation. Soil Science, 163, 241-247. http://dx.doi.org/10.1097/00010694-199803000-00009

[9] Halvorson, A.D., Reule, C.A. and Follett, R.F. (1999) Nitrogen Fertilization Effects on Soil Carbon and Nitrogen in a Dryland Cropping System. Soil Science Society of America Journal, 63, 912-917. http://dx.doi.org/10.2136/sssaj1999.634912x

[10] Scott, H.D., Ferguson, J.A., Hanson, L., Fugitt, T. and Smith, E. (1998) Agricultural Water Management in the Mississippi Delta Region of Arkansas. Arkansas Agricultural Experiment Station, Division of Agriculture, University of Arkansas, Fayetteville.

[11] Cordell, M.L., Brye, K.R., Longer, D.E. and Gbur, E.E. (2006) Residue Management Practice Effects on Soybean Establishment and Growth in a Young Wheat-Soybean Double-Cropping System. Journal of Sustainable Agriculture, 29, 97-120. http://dx.doi.org/10.1300/J064v29n02 08

[12] Brye, K.R., Mersiovsky, E., Hernandez, L. and Ward, L. (2013) Soils of Arkansas. Arkansas Agricultural Experiment Station, University of Arkansas System Division of Agriculture, Fayetteville, AR. 136 p.

[13] Natural Resources Conservation Service (NRCS), Soil Survey Staff (2012) Web Soil Survey: Soil Data Mart. http://websoilsurvey.nrcs.usda.gov

[14] Brye, K.R., Cordell, M.L., Longer, D.E. and Gbur, E.E. (2006) Residue Management Practice Effects on Soil Surface Properties in a Young Wheat-Soybean Double-Crop System. Journal of Sustainable Agriculture, 29, 121-150. http://dx.doi.org/10.1300/J064v29n02 09

[15] National Oceanic and Atmospheric Administration (NOAA) (2002) Climatography of the United States No. 81, Monthly Station Normals of Temperature, Precipitation, and Heating and Cooling Degree Days 1971-2000: Arkansas. United States Department of Commerce, National Climatic Data Center, Asheville.

[16] Verkler, T.L., Brye, K.R., Popp, J.H., Gbur, E.E., Chen, P. and Amuri, N. (2009) Soil Properties, Soybean Response, and Economic Return as Affected by Residue and Water Management Practices. Journal of Sustainable Agriculture, 33, 716-744. http://dx.doi.org/10.1080/10440040903220724

[17] University of Arkansas Cooperative Extension Service (UACES) (2000) Arkansas Soybean Handbook. Miscellaneous Publication 197. Cooperative Extension Service, University of Arkansas, Little Rock.

[18] Norman, C.R. (2015) Long-Term Effects of Alternative Residue Management Practices on Near-Surface Soil Properties and Soybean Production in a Wheat-Soybean, Double-Crop System in Eastern Arkansas. M.S. Thesis, University of Arkansas, Fayetteville.

[19] Slaton, N., Roberts, T. and Ross, J. (2013) Fertilization and Liming Practices. In: Extension Soybean Commodity Committee, Ed., Arkansas Soybean Production Handbook, University of Arkansas Research and Extension, Little Rock. http://www.uaex.edu/publications/pdf/mp197/chapter5.pdf

[20] Shaver, T.M., Peterson, G.A., Ahuja, L.R., Westfall, D.G., Sherrod, L.A. and Dunn, G. (2002) Surface Soil Physical Properties after Twelve Years of Dryland No-Till Management. Soil Science Society of America Journal, 66, 12961303. http://dx.doi.org/10.2136/sssaj2002.1296

[21] Dao, T.H. (1993) Tillage and Winter Wheat Residue Management Effects on Water Infiltration and Storage. Soil Science Society of America Journal, 57, 158-159. http://dx.doi.org/10.2136/sssaj1993.03615995005700060032x 